\title{
Legal Protection of Women In Un-Official Inter-Citizen Marriage
}

\author{
Ramdani Wahyu Sururie ${ }^{1} \&$ Dio Ashar Wicaksana ${ }^{2}$
}

\begin{abstract}
Legal Protection of Women In Un-Official Inter-Citizen Marriage. The phenomenon of un-official inter-citizen marriage has been rife in several places in Indonesia. As a result of such marriages, women often have no legal power and can not obtain legal identity rights such as marriage certificates, birth certificates for their children, including material rights such as joint property and property ownership. This study examines the process of informal marriages between citizens as well as examining the extent to which the state provides legal protection to women who engage in informal marriage. The method and approach taken are normative juridical by utilizing secondary data sources in the form of legislation, books, and scientific journals. The results show that the emergence of an unofficial inter-citizen marriage is mostly due to the incompleteness of the documents needed from the country of origin of the prospective husband. To overcome this problem, the state has protected women in the form of preventive and restitutive protection women involved in intermarriages can obtain a clear legal position and protection.
\end{abstract}

Keywords: un-official inter-citizen marriage, is $b \bar{a} t$ nikāh, religious court, marriage law

\begin{abstract}
Abstrak: Perlindungan Hukum Terhadap Perempuan Dalam Perkawinan Campuran di Bawab Tangan. Fenomena perkawinan antar warga negara yang tidak resmi marak terjadi di beberapa tempat di Indonesia. Akibat perkawinan semacam ini seringkali perempuan tidak memiliki kekuatan hukum dan tidak dapat memperoleh hak identitas hukum seperti akta nikah, akte lahir bagi anaknya termasuk hak-hak kebendaan seperti harta bersama dan kepemilikan property. Studi ini mengkaji proses perkawinan tidak resmi antar warga negara sekaligus mengkaji sejauhmana negara memberikan perlindungan hukum kepada perempuan yang melakukan perkawinan di bawah tangan. Metode dan pendekatan yang dilakukan adalah bersifat yuridis normatif dengan memanfaatkan sumber data sekunder berupa peraturan perundang-undangan, buk-buku dan jurnal ilmiah. Hasil penelitian menunjukkan bahwa timbulnya perkawinan campuran di bawah tangan dilatarbelakangi ketidaklengkapan dokumen yang dibutuhkan dari negara asal calon suami sehingga perkawinannya tidak dapat dicatatkan ke KUA. Untuk mengatasi hal itu, negara telah memberikan perlindungan kepada pihak perempuan dalam bentuk perlindungan preventif dan restitutif. Melalui cara ini perempuan yang terlibat dalam perkawinan campuran dapat memperoleh kedudukan dan perlindungan hukum yang jelas.
\end{abstract}

Kata Kunci: perkawinan campuran, isbāt nikāh, Pengadilan Agama, Undang-Undang Perkawinan

\footnotetext{
${ }^{1}$ Universitas Islam Negeri Sunan Gunung Djati Bandung

${ }^{2}$ Ońati International Institute For The Sociology Of Law, Gipuzkoa-Spain

E-mail: ${ }^{1}$ ramdani.wahyu@uinsgd.ac.id, 2dioashar07@gmail.com
} 


\section{Introduction}

Marriage Law No. 1 of 1974 regulates in detail about intermarriage. Article 57 defines that intermarriage is a marriage between two person of different nationality in which one of the party has a foreign nationality and another party has an Indonesian nationality. ${ }^{1}$ Thus, the intermarriages, according to this law, can occur when: 1) An Indonesian male citizen marries a foreign woman or 2) An Indonesian woman marries a male foreigner.

Previously, intermarriages could be interpreted as marriages between different ethnicities, nationalities, or religions. However, after the enactment of Law Number 1 of 1974, the meaning of intermarriages became narrower than the existing understanding both according to law and jurisprudence about intermarriages before the promulgation of Law Number 1 of $1974 .^{2}$ Thus, marriages between two people of different groups (Javanese and Papuanese) or different religions (Islam and Christianity) but equally Indonesian, are not accommodated as intermarriages according to the Act due to the similarity in citizenship.

Basically, marriage is intended to form a family that lasts a lifetime and is not just broken ${ }^{3}$. Within the lifetime marriage, families can prepare a superior generation for nation-building. In other words, marriages based on a strong nationality and religious foundation will become a pillar of national development. To carry out a marriage, each spouse must pay attention to the provisions of Article 1 paragraph (2) of the Marriage Law, that marriages must be recorded according to the provisions of the applicable legislation. If a marriage is found uncertified, the marriage, then, is considered to have no legal force. A Marriage without a certificate, in the view of the Law, is considered to have no proof of marriage so

${ }^{1}$ Rahmadi Indra Tektona, 'Perlindungan Hukum Perempuan Terhadap Anak Hasil Perkawinan Campuran di Indonesia (Perspektif Socio-Legal)', MUWAZAH: Jurnal Kajian Gender, p. 442 <http://e-journal.iainpekalongan.ac.id/index.php/Muwazah/article/view/267>.

2 Sri Budi Purwaningsih, 'Perlindungan Hukum Kedudukan Anak Luar Kawin Pasca Putusan Mahkamah Konstitusi No: 46/PUU-VIII/2010', Jurnal Rechtsidee, 1.1 (2014), 5 (p. 5).

${ }^{3}$ Laurensius Arliman S, 'Peran Lembaga Catatan Sipil Terhadap Perkawinan Campuran Berdasarkan Undang-Undang Perkawinan', JCH (Jurnal Cendekia Hukum), 4.2 (2019), 288-301 (p. 291) <https://doi.org/10.33760/jch.v4i2.40>. 
that when disputes occur in the future it will be difficult for various parties. It is under such a situation that marriages in Indonesia must follow Indonesian marriage law, not only it meets certain standards but it also must be officially registered by certain institutions (KUA). ${ }^{4}$

Provisions regarding the registration of marriages, as stated in Article 1 paragraph (2) above, will provide legal certainty and legal protection for people who carry out marriages. A registered marriage will issue a marriage certificate as well as the legality and legal protection, including guarantees of legal certainty such as the mutual rights and obligations of husband and wife, joint property, the status of children, etc. ${ }^{5}$

The same applies to intermarriages between different citizens. Couples in intermarriages will surely encounter a variety of legal issues, concerning the citizenship status of each party, their children's status, including ownership of immovable property, because they subject to different laws. ${ }^{6}$ That is why, in various society in Indonesia, many people do not support inter-citizen marriage, among others is in the Sabang people, as they considered it worthless and better avoided on account of the issue of different customs, origin offspring, and religion Thus, based on the concern, marrying a different spouse of citizens will only hamper harmony in their families that finally lead to divorce. ${ }^{7}$

Apart from the various obstacles and difficulties that loomed over the marriage, however, the practice of intermarriages continues to flourish in several places in Indonesia, with diverse backgrounds and motivations. In the Iboh-Sabang region, for instance, according to a

${ }^{4}$ Darwis L. Rampay, 'Hak Waris Anak dalam Perkawinan Campuran Berdasarkan UndangUndang Nomor 12 Tahun 2006 Tentang Kewarganegaraan', MORALITY : Jurnal Ilmu Hukum, p. $6<$ http://jurnal.upgriplk.ac.id/index.php/morality/article/view/27>.

${ }^{5}$ Nenan Julir, 'Pencatatan Perkawinan di Indonesia Perspektif Ushul Fikih', Jurnal Ilmiah Mizani: Wacana Hukum, Ekonomi dan Keagamaan, 4.1 (2018), 53-62 (P. 3) <Https://Doi. Org/10.29300/Mzn.V4i1.1010>.

${ }^{6}$ Ahmadika Safira Edithafitri, 'Status Kepemilikan Benda Tidak Bergerak dalam Perkawinan Campuran di Indonesia', LEX PRIVATUM, 3.1 (2015), p. 74 <https://ejournal.unsrat.ac.id/index. $\mathrm{php} /$ lexprivatum/article/view/7027> .

${ }^{7}$ Mursyid Djawas and Nurzakia Nurzakia, 'Perkawinan Campuran di Kota Sabang (Studi Terhadap Faktor dan Persepi Masyarakat Tentang Dampak Perkawinan Campuran)', SAMARAH: Jurnal Hukum Keluarga dan Hukum Islam, 2.2 (2019), 307-34 (p. 310) <https://doi.org/10.22373/ sjhk.v2i2.4740>. 
report from KUA of Sukakarya District, there are as many as seven couples of intermarriages that occurred in the past few years. In tourist areas such as Bali, Kalimantan, Lombok, and others, the number of intermarriages increases significantly every year. In Bali, based on a study, intermarriage continued to increase throughout the years 2015-2018. ${ }^{8}$ This tendency shows that currently in Indonesia, intermarriages are a common occurrence by foreign and Indonesian couples. Cultural diversity and citizens' differences are no longer barriers or restrictions for establishing marital relations with foreign nationals.

The phenomenon of intermarriages is motivated by a variety of motives. Some are motivated by love, some are motivated by economic, some by practical issues such as ease in getting a residence permit from the Indonesian government, and many other motives that are only known by those who engage in intermarriages. Even, in certain circles, there is a tendency for intermarriages to be a pride for individuals who do so. In Bali, for instance, the main motive of foreign men/women marrying Indonesian women/men is to obtain convenience in obtaining a residence permit from the Indonesian government. Besides, there is also a desire to own land whose ownership status can only be obtained through marriage with Indonesian citizens. ${ }^{10}$ In West Kalimantan province, intermarriages are mostly motivated by economic factors where Taiwanese foreigners tend to prefer to marry Indonesian women because marrying Indonesian women is cheaper than marrying women from their home country.

Unfortunately, such intermarriages are often done unregistered in the special institution that deals with the matter, namely in the Office of Religious Affairs (KUA), for those who are Muslim, and in the Civil Registry Office for those whose religion is other than Islam. The bride and groom should be aware that unregistered intermarriages may result in

${ }^{8}$ Siah Khosiah, dkk., Isbāt Nikāh Atas Perkawinan Campuran Pada Wilayah Wisata Di Indonesia (Bandung: Lembaga Penelitian dan Pengabdian kepada Masyarakat, 2018), pp. 90-91.

${ }^{9}$ R. Damayanti., Kajian Akademis Rencana Program 30 Tahun Menghadirkan Manusia Indonesia Baru (Peluang Pengkondisian Perkawinan Antar Etnis, Ras, Bangsa dan Agama di Indonesia) (Jakarta: Kementerian Pemberdayaan Perempuan dan Perlindungan Anak. Pusat Penelitian Kesehatan Universitas Indonesia, 2015), p. 15.

${ }^{10}$ Nur Faiz (A Judge ini Badung Religious Court), Motivasi orang menikahi pribumi, 2018. 
many unpleasant, legal consequences, especially for women. Not only will the marriage have no legal force for both parties, but it also will impact on the status of their children, including access and material rights that are generally owned by registered married couples. This means that the issue of intermarriages is important that requires careful study, especially if it is related to the legal status of Indonesian women involving in the intermarriage.

\section{Intermarriage Processes}

The process of implementing intermarriage is the same as implementing a non-intermarriage. What distinguishes the two lies in fulfilling administrative requirements. According to Regulation of the Minister of Religion of the Republic of Indonesia Number 19 of 2018 concerning Marriage Registration, as stated in Article 24, before the registration of intermarriage, the bride and groom who is a foreign national must fulfill several requirements such as permission from the embassy/representative of the country concerned or from the relevant country's authorized agent of the prospective bride/groom., photocopy of passport, photocopy of birth certificate, divorce certificate/death certificate for widower and widow, the data of both parents of foreign nationals following the data on the marriage certificate of the bride and groom's country of origin, polygamy permit from the religious court or authorized institution in the country of origin for a husband who wants to have more than one wife. Besides, the bride and groom must also fulfill and oath statement and a marriage certificate from the embassy or country concerned. All of the required documents are translated into Indonesian. Once all of the requirements completed, an excerpt from a marriage certificate from the office of religious affairs (KUA) can be issued, ensuring the protection of the perpetrators. ${ }^{11}$

${ }^{11}$ M. Nur Kholis Al Amin, 'Perkawinan Campuran dalam Kajian Perkembangan Hukum: Antara Perkawinan Beda Agama dan Perkawinan Beda Kewarganegaraan di Indonesia', AlAhwal: Jurnal Hukum Keluarga Islam, p. 218 <http://ejournal.uin-suka.ac.id/syariah/Ahwal/ article/view/09206>. 
The difference in the process of intermarriages that are recorded in KUA with unregistered lies in the necessity of permission from the embassy of the country of origin for the bride and groom of different nationality. ${ }^{12}$ In unregistered intermarriages, the practice of intermarriages is carried out not by supervision of the Registrar of Marriage from an authorized institution (KUA) but by parents as guardians, attended by both bride and groom, and witnesses. In the view of Islamic Law, such practice is valid although it does not involves a registrar of Marriage.

Based on the result of a study, three main reasons encourage the parties who engage in intermarriages not to register their marriages to the KUA, namely:

1. Documents owned by foreign husbands cannot be fulfilled or issued from the country of origin while the family of the wife has urged to immediately carry out the marriage;

2. The parents are worried that adultery will occur so that the process of speeding up marriage is an inevitable choice;

3. Applicants were not aware that the function of registered marriage as well as the marriage certificate is a very important legal document in obtaining other legal documents.

For the first reason, as stated by the clerk of the Denpasar and Tabanan Religious Court, most of the unregistered intermarriages occur because of the complexity of the process and the length of time required to obtain a document in the form of a CNI (Certificate of No Impediment) or a marriage permit issued by embassies of prospective husbands. ${ }^{13}$ It must be admitted that for certain countries such as Japan and Australia, CNI documents can easily be obtained at embassies, consulates, or attaches that are close to the Province of Bali. For certain other countries, however, such as Germany and Korea, getting a certificate from the Ambassador of the country of origin will take a long time and needs to be translated

${ }^{12}$ Nur Anisah, 'Pelaksanaan Perkawinan Campuran di KUA Tahunan, Jepara dalam Tinjauan Undang-Undang Perkawinan di Indonesia', Isti dal : Jurnal Studi Hukum Islam, p. $18<\mathrm{https://}$ ejournal.unisnu.ac.id/JSHI/article/view/854>.

${ }^{13}$ Karyadi and Mursal, (Registrars in Religious Court of Denpasar and Tabanan), 2018. 
into Indonesian by those who need it. This is what causes intermarriages can not be recorded at the local KUA. ${ }^{14}$

The second reason why intermarriages are not recorded at the KUA can be understood from the decision of the Religious Court of Badung region No: 0019/Pdt.P/ 2017/PA.Bdg. In this case, the marriage of the applicant has been held in Islam but not registered at the KUA. According to the panel of judges, the unregistered marriage occurred not due to negligence or intention of Petitioner I and Petitioner II but was caused by the parents of Petitioner II's father who urged to avoid adultery so that the marriage was carried out without preparation and was not formally registered by the authorized official. ${ }^{15}$ This causing factor also can be found in the posita written in the stipulation No: 0015/Pdt.P/2015/PA.Dps. ${ }^{16}$

The third reason, though not revealed clearly, is the ignorance of married couples regarding the importance of marriage registration. Such an assumption can be found from the background of the case for the marriage ratification application submitted to the Religious Court. When referring to the reasons that emerged in the Courts hearing in the Cianjur and the Tigaraksa Religious Court of West Java, for example, it is reasonable to suspect that the reasons not to register intermarriages were due to the ignorance of the applicants. This study, however, has not succeeded in uncovering the reasons behind unregistered intermarriages in the KUA of the Bali region. Based on the results of interviews with the Head of KUA of South Kuta District, it was found that the reasons for the marriages of foreigners which were not recorded in the KUA of South Kuta District were mostly unknown. Allegedly, there was pressure from the family of the woman or also local clerics who wanted the marriage to be done immediately to prevent adultery. ${ }^{17}$ These reasons can also be traced in several Religious Court Decisions in Bali Region (Badung and Denpasar), such as Decision No. 0025/ Pdt.P/2015/PA.Bdg, Decision No

\footnotetext{
${ }^{14}$ Masruhan (Head of Religious Court of Southern Kuta Region), 2018.

${ }^{15}$ Mahmudah, (A Judge of Religious Court of Badung), 2018.

${ }^{16}$ Karyadi and Mursal, (Registrars in Religious Court of Denpasar and Tabanan), 2018.

${ }^{17}$ Karyadi and Mursal, (Registrars in Religious Court of Denpasar and Tabanan), 2018.
} 
0008/Pdt.P/2016/PA.Bdg, Decision of Cianjur Religious Court No.1172/ Pdt.P/2016/PA. Cjr, Decision No. 0004/Pdt.P/2016/ PA.Cjr, Decision No. 0151/Pdt.P/2018/PA.Cjr, and the Decision of Tigaraksa Religious Court No. 0362/Pdt.P/2017/PA.Tgrs.

Because unregistered intermarriages are not recorded in the documents of the authorized institutions, practically married couples will not obtain a marriage certificate. The absence of this certificate, if no solution is provided, will cause the parties to experience obstacles in obtaining certain other documents that require proof of marriage. Therefore, the law permits to married couples who are not officially married to apply for so-called is $\bar{a} t$ nikāh (the recognition of marriage) to the Religious Court to obtain recognition from the state for the status of their marriage and that means that they will get the same status and rights as married couples whose marriages were registered.

In general, the reasons for applying isbāt nikāh are similar, namely to obtain a legal identity in the form of a marriage certificate. The position of the marriage certificate for married couples is very important because it is an authentic document that explains that the event of marriage has occurred between one individual and another individual. With legal recognition of their marital events, a husband/wife, including children born from such marriages, will obtain the legal status and certain rights they need for the survival of their household life.

For foreigners, with the legality of their marriage, residence permits, and other material rights they can easily obtain. Apart from that, a husband/wife of a foreign national who has assets in their marriage can have the rights to those assets if he/she has signed a previous agreement. This agreement is necessary because Indonesian law adopts the principle of nationalism, in which only Indonesian citizens can have land rights as stated in the Agrarian Law (UUPA) No. 5/1960 regarding land. By making agreements signed before the wedding, the foreign spouse can have these rights because he/she has the same legal position as his partner does. ${ }^{18}$ The recognition of marriage (is $\bar{a} \bar{t} t$ nikăh) has a great function and

${ }^{18}$ Justitia Henryanto Ghazaly, 'Kepemilikan Hak Atas Tanah Dalam Perkawinan Campuran', 
benefit for both parties, where foreigners need the legality of marriage and Indonesian citizens need it for their future marriages.

Although, in general, the reason for the parties applying for the recognition of marriage (isbāt nikāh) is to obtain legal recognition in the form of a marriage certificate for a marriage that they have done before, there are also other reasons proposed by the applicants as illustrated in the following table:

Table 1. Reasons for Applying for Isbāt Nikāh (Marriage Acknowledgment)

\begin{tabular}{|c|c|c|c|c|c|}
\hline No & Case number & $\begin{array}{l}\text { Petitioner } \\
\text { I }\end{array}$ & $\begin{array}{l}\text { Petitioner } \\
\text { II }\end{array}$ & $\begin{array}{l}\text { Reasons for Applying } \\
\text { for isbāt nikāb }\end{array}$ & $\begin{array}{c}\text { Place / Year of } \\
\text { Marriage }\end{array}$ \\
\hline 1 & $\begin{array}{l}\text { 0015/ Pdt.P/ } \\
\text { 2015/ PA. Dps }\end{array}$ & $\begin{array}{l}\text { Dutch } \\
\text { Citizen }\end{array}$ & Denpasar & $\begin{array}{l}\text { To obtain marriage } \& \\
\text { birth certificate }\end{array}$ & $\begin{array}{l}\text { Pangandaran } \\
\text { in } 2013\end{array}$ \\
\hline 2 & $\begin{array}{l}\text { 0025/Pdt.P/2015/ } \\
\text { PA.Bdg }\end{array}$ & $\begin{array}{l}\text { British } \\
\text { Citizen }\end{array}$ & Kuta & $\begin{array}{l}\text { To obtain a marriage } \\
\text { certificate }\end{array}$ & Kuta in 2013 \\
\hline 3 & $\begin{array}{l}\text { 0008/Pdt.P/2016/ } \\
\text { PA.Bdg }\end{array}$ & $\begin{array}{l}\text { Korea } \\
\text { Citizen }\end{array}$ & Kuta & $\begin{array}{l}\text { To obtain a marriage } \\
\text { certificate }\end{array}$ & Kuta in 2013 \\
\hline 4 & $\begin{array}{l}\text { 0006/Pdt.P/2017/ } \\
\text { PA.Bdg }\end{array}$ & $\begin{array}{l}\text { Dutch } \\
\text { Citizen }\end{array}$ & Kuta & $\begin{array}{l}\text { To obtain a marriage } \\
\text { certificate }\end{array}$ & $\begin{array}{l}\text { Bojong, } \\
\text { Soreang, } \\
\text { Bandung, in } \\
2002\end{array}$ \\
\hline 5 & $\begin{array}{l}\text { 0019/Pdt.P/2017/ } \\
\text { PA.Bdg }\end{array}$ & $\begin{array}{l}\text { New } \\
\text { Zealand } \\
\text { Citizen }\end{array}$ & Kuta & $\begin{array}{l}\text { To obtain a marriage } \\
\text { certificate }\end{array}$ & $\begin{array}{l}\text { Pusakanagara } \\
\text { Subang, in } \\
2010\end{array}$ \\
\hline 6 & $\begin{array}{l}\text { 0004/Pdt.P/2018/ } \\
\text { PA.Cjr }\end{array}$ & $\begin{array}{l}\text { Pakistan } \\
\text { Citizen }\end{array}$ & Cianjur & $\begin{array}{l}\text { To obtain marriage } \\
\text { certificate \& Child } \\
\text { status }\end{array}$ & $\begin{array}{l}\text { Married in } \\
2003\end{array}$ \\
\hline 7 & $\begin{array}{l}\text { 0151/Pdt.P/2018/ } \\
\text { PA.Cjr }\end{array}$ & $\begin{array}{l}\text { Saudi } \\
\text { Arabia } \\
\text { Citizen }\end{array}$ & Cianjur & $\begin{array}{l}\text { To obtain a marriage } \\
\text { certificate \& Child } \\
\text { status }\end{array}$ & $\begin{array}{l}\text { Married in } \\
2003\end{array}$ \\
\hline 8 & $\begin{array}{l}\text { 1172/Pdt.P/2016/ } \\
\text { PA.Cjr }\end{array}$ & $\begin{array}{l}\text { China } \\
\text { Citizen }\end{array}$ & Cianjur & $\begin{array}{l}\text { To obtain a marriage } \\
\text { certificate }\end{array}$ & $\begin{array}{l}\text { Married in } \\
2010\end{array}$ \\
\hline 9 & $\begin{array}{l}\text { 004/Pdt.P/2017/ } \\
\text { PA.Tgrs }\end{array}$ & $\begin{array}{l}\text { Mali } \\
\text { Citizen }\end{array}$ & $\begin{array}{l}\text { Tangerang } \\
\text { Selatan }\end{array}$ & $\begin{array}{l}\text { To obtain a marriage } \\
\text { certificate }\end{array}$ & $\begin{array}{l}\text { Married in } \\
2015\end{array}$ \\
\hline
\end{tabular}

Jch (Jurnal Cendekia Hukum), 5.1 (2019), 117-30 (p. 122) <https://doi.org/10.33760/jch. v5i1.183>. 


\begin{tabular}{|c|c|c|c|c|c|}
\hline No & Case number & $\begin{array}{l}\text { Petitioner } \\
\text { I }\end{array}$ & $\begin{array}{l}\text { Petitioner } \\
\text { II }\end{array}$ & $\begin{array}{l}\text { Reasons for Applying } \\
\text { for isbāt nikāb }\end{array}$ & $\begin{array}{c}\text { Place / Year of } \\
\text { Marriage }\end{array}$ \\
\hline 10 & $\begin{array}{l}\text { 616/Pdt.P/2017/ } \\
\text { PA.Tgrs }\end{array}$ & $\begin{array}{l}\text { China } \\
\text { Citizen }\end{array}$ & $\begin{array}{l}\text { Tangerang } \\
\text { Selatan }\end{array}$ & $\begin{array}{l}\text { To obtain a marriage } \\
\text { certificate }\end{array}$ & $\begin{array}{l}\text { Married in } \\
2015\end{array}$ \\
\hline 11 & $\begin{array}{l}\text { 070/Pdt.P/2018/ } \\
\text { PA.Tgrs }\end{array}$ & $\begin{array}{l}\text { Oman } \\
\text { Citizen }\end{array}$ & $\begin{array}{l}\text { Tangerang } \\
\text { Selatan }\end{array}$ & $\begin{array}{l}\text { To obtain a marriage } \\
\text { certificate }\end{array}$ & $\begin{array}{l}\text { Married in } \\
2017\end{array}$ \\
\hline 12 & $\begin{array}{l}\text { 184/Pdt.P/2018/ } \\
\text { PA.Tgrs }\end{array}$ & $\begin{array}{l}\text { Korea } \\
\text { Citizen }\end{array}$ & $\begin{array}{l}\text { Tangerang } \\
\text { Selatan }\end{array}$ & $\begin{array}{l}\text { To obtain a marriage } \\
\text { certificate }\end{array}$ & $\begin{array}{l}\text { Married in } \\
2011\end{array}$ \\
\hline 13 & $\begin{array}{l}\text { 0362/Pdt.P/2018/ } \\
\text { PA.Tgrs }\end{array}$ & $\begin{array}{l}\text { Saudi } \\
\text { Arabi } \\
\text { Citizen }\end{array}$ & $\begin{array}{l}\text { Tangerang } \\
\text { Selatan }\end{array}$ & $\begin{array}{l}\text { To obtain a marriage } \\
\text { certificate }\end{array}$ & $\begin{array}{l}\text { Married in } \\
2013\end{array}$ \\
\hline
\end{tabular}

Source: Processed from the Decisions of Isbāt Nikäh in the Badung, Denpasar, Cianjur and the Tigaraksa Religious Courts

\section{Legal Protection for Women in Uncertified Inter-Marriage}

The practice of intermarriages in Indonesia provides status and rights that are recognized by law such as the right to obtain shared property, the right to inherit, the right to receive a living and child parenting, etc. ${ }^{19}$ These rights can be obtained if the intermarriages are carried out according to the law, namely having a marriage certificate. In contrast, uncertified intermarriage that does not have a marriage certificate is considered to have no legal force. Therefore, an Indonesian who marry foreigners without a Registrar of marriage involvement will not obtain the status recognized by law and may lose some material rights including child nurturing rights. The consequences of the intermarriage must be understood by Indonesian women to prevent them from losing their rights as affirmed by Sebastian Partogi, Awareness of the Marriage Law is essential for Indonesian women who marry foreigners to retain their land rights. Indonesian women who marry foreigners need to have sufficient

${ }^{19}$ Couples in intermarriages are also allowed to adopt children. The promotion of children for intermarriages, which is also known as intercountry adoptions, follows the provisions of Government Regulation No. 54 of 2007 concerning the Implementation of Child adoption. Read Yunanto Raesa Astiti Putri, 'Pengangkatan Anak Warga Negara Indonesia Oleh Orang Tua Angkat dalam Perkawinan Campuran di Indonesa (Studi Kasus : Pengangkatan dalam Kasus Angeline di Bali)', Diponegoro Law Journal, 5.2 (2016), 1-13. 
understanding of the 1974 Marriage Law, the 1958 Citizenship Law, and the 1960 Agrarian Law to enable them to retain their right to own freehold property". ${ }^{20}$ This means that intermarriages conducted by Indonesian women with men from different countries need to receive protection from the government. This can be done in two forms, namely preventive legal protection and restitutive legal protection.

Preventive legal protection means that the law protects Indonesian women before engaging in intermarriages to know that their rights are guaranteed by law. Preventive legal protection also means preventing women from arbitrary actions that may be experienced by women in their marriages. Preventive legal protection for women in intermarriages can be traced from statutory regulations. Before the enactment of Law No. 1 of 1974, Indonesia used the Intermarriage Ordinance, No. 158/1898, in Article 3 which states that a woman who engages in intermarriage follows her husband's status both in public and civil law. ${ }^{21}$ But after the enactment of Law No. 1 of 1974, the intermarriages issues were more specifically regulated in articles 57-62.

Apart from the above provisions, preventive legal protection for women in intermarriages can also be found in the marriage law and citizenship law. The commentary on articles relating to legal protection in Marriage Law Number 1 of 1974 Article 2 Paragraph (1) and Paragraph (2) which states that "marriages are declared valid if it complies with the religious and marriage provisions and is officially registered."

This article is a form of preventive protection so that every intermarriage should be carried out under religious regulations and recorded by the Registrar of Marriage. The consequences of unregistered marriages found in Law Number 1 of 1946 concerning Marriage, Talak, and Reconciliation Registration, wherein article 3 it is stated that "those who make a marriage contract with a woman and are not carried out

${ }^{20}$ Sebastian Partogi., 'Implications of Mixed Marriage for Indonesian Women', Property Ownership - Business - The Jakarta Post', p. 7 <https://www.thejakartapost.com/news/2015/09/12/ implications-mixed-marriage-indonesian-women-s-property-ownership.html>.

${ }^{21}$ Mutiara Hikmah, 'Perlindungan Hak-Hak Perempuan dalam Perkawinan Campuran Berdasarkan Instrumen-Instrumen Internasional Tentang Hak Asasi Manusia', Indonesian Journal of International Law, 3.4 (2006), 625-641-641 (p. 633) <https://doi.org/10.17304/ijil.vol3.4.126>. 
under the marriage registration clerk will be punished as much as a fine amounted to R 50 (fifty rupiahs)". Likewise, sanctions for intermarriages which are not recorded as stated in the Material Law of Religious Court Bill Article 143 that anyone who is intentionally married not before a Marriage Registry Officer is fined as much as Rp. 6,000.0000 (six million rupiahs) or a maximum in jail of 6 (six) months. Such sanctions are similar to those in other countries in the world, for example in Iran where marriages carried out without the registration of the authorities are sanctioned with imprisonment of 1 to 6 months, or a fine of 200 dinars or 2 years imprisonment Similarly, in Jordan, the perpetrators of the unregistered marriage are fined as much as 1,000 dinars. ${ }^{22}$

The existence of marriage certificate documents for intermarriages in Indonesia is very vital. A married couple in intermarriage whose marriages are registered will obtain a legal identity. The legal identity referred to here is a proof of legal identity that is owned by someone, one of which is in the form of a marriage certificate/book. A marriage certificate/book in Indonesia is a document that can be issued by two authorized parties: the Office of Religious Affairs for Muslim people and the Office of Civil Registration for non-Muslims. This marriage certificate/book is a legal document that proves the marriage status of a couple based on marriage registration under Law No. 1 of 1974 concerning Marriage, and Law No. 23 of 2006 concerning Population Administration in conjunction with Law Number 23 of 2013.

Conversely, those who engage in unregistered marriages or fails to prove the existence of a marriage or to show the certificate will result in difficulties in obtaining a legal identity. This situation clearly will bring harm to the husband, wife, and children of the family. Husbands and wives of unregistered marriages cannot claim any rights one to another, similarly, it will be difficult for children to obtain birth certificates and other important documents because in the eyes of law such marriages are considered never exist.

${ }^{22}$ Nasaruddin Umar, 'Hukum Keluarga Kontemporer di Negara-Negara Muslim' (presented at the Seminar Nasional Hukum Materil Peradilan Agama, Antara Cita, Realita dan Harapan, Hotel Red Top, Jakarta, 2010), p. 8. 
The only way out to make these intermarriages recorded and have a marriage certificate or book is by submitting the request of the socalled isbāt nikāh (marriage recognition) to the Religious Court. With the existence of this legal solution, it is not surprising that the number of requests for isbāt nikāh) in 359 Religious Courts in Indonesia tripled, as well as cases that were heard through itinerant courts at the village level doubled. In 2012, a study reported, more than 23,000 cases were heard in the Religious Courts and in .2013, the number of cases increased significantly to more than 35,000 cases. This data shows that the involvement of the religious court in facilitating the community seeking the rights of legal identity is very dominant, showing reasonable argument if, in the future, the government establishes a mechanism that will facilitate the poor in obtaining such facilities. ${ }^{23}$

Furthermore, another form of legal protection for Indonesian women engaging of intermarriages is restitutive protection. This form of protection restores the situation from nothing, without legal status, to being of legal status. In Law Number 1 of 1974 concerning marriage, it is stated that. unregistered marriages are seen as without legal force and the perpetrators can be fined. However, to realize legal certainty and protection, the state provides another door for couples to engage in intermarriages through a mechanism known as isbät nikäh (marriage recognition). This solution is seen as a form of restitutive legal protection, i.e. restoring from being without legal status to being legally enforceable. Thus, the essence of isbät nikäh itself turns to discretion between articles in the Marriage Law. ${ }^{24}$

It should be noted, however, that isbāt nikāh means the recognition of marriage and not justification. Such is so because the marriage which was submitted to the Religious Court is essentially valid according to religious provisions. According to the Book II of Guidelines for the

${ }^{23}$ Cate Sumner dkk, Studi Dasar AIPJ Tentang Identitas Hukum Jutaan Orang Tanpa Identitas Hukum di Indonesia. (Jakarta: DFAT, 2014), p. 9.

${ }^{24}$ Ramdani Wahyu Sururie., 'Polemik di Seputar Hukum Isbāt Nikāh dalam Sistem Hukum Perkawinan Indonesia', Al-Manahij: Jurnal Kajian Hukum Islam, p. 237 <http://ejournal. iainpurwokerto.ac.id/index.php/almanahij/article/view/1299>. 
Implementation of Duties and Administration in the Religious Courts, Revised Edition $(2011 ; 148)$, the requests of isbāt nikāh can be made by both husband and wife or one of the husband and wife, children, marriage guardians or other parties to the Religious Court or the Shariah Court in the jurisdiction of the applicant residency. The requests for marriage recognition must be accompanied by clear and concrete reasons and interests. The panel of judges will consider various evidence of the unregistered marriage cases either in the form of witness statements or legal facts at the hearing.

The existence of the provisions regarding recognition of marriage (isbät nikāh) in Indonesian law is a form of renewal of Islamic law as well as restitutive protection for married couples engaging in uncertified intermarriage. This is because until now the community's obedience, especially in the Muslim community, to the provisions of marriage registration has not been optimum. There are still ambiguous attitudes from the community towards marital regulations in Indonesia, whether they obey the state regulations that require the registration of marriages or obey the fiqh rules that do not recognize the registration as part of the elements that determine the validity of the marriage. If examined using the theory of maslahah and the maqāsid sharīah of Al-Syathibi, the provisions regarding the recording of marriage contain elements of benefit for Muslims, especially if it is related to the realities below:

1. In this age where the population increase significantly, data collection in the form of population registration whether birth, marriage, divorce, death, etc., is necessary. Because if it is not done it will lead to disorder in social life, which in turn may lead to legal smuggling.

2. By not recording the marriage, protection of the rights of family members (husband, wife, and children) in the form of rights to property, marital status or rights to self-identity cannot be obtained. This results in primary goals of marriage in the form of hifdz al-nasl (maintaining descent/honor) and hifdz al-mäl (preserving property) can not be fulfilled. Thus the regulation of marriage recognition (Isbāt Nikāh) for uncertified intermarriage in necessary, aiming at protecting against adversity/loss of family members' rights while 
at the same time providing benefits for them in the form of legal protection.

3. The benefit arising from the provision of Isbät Nikäh is general, not individual. In other words, the provisions apply for all people, not limited to individuals, religions or certain groups. This is in line with the principle of fiqh: المصلحة العامة مقدمة على المصلحة الخاصة (Public benefit must take precedence over the benefit of the individual". 25

4. Normatively, the marriage law has embodied the principles contained in the Pancasila and the 1945 Constitution and has accommodated all aspects of factual life and the Religious Law in the community as well. ${ }^{26}$ Therefore, the implementation of the provisions of isbatt nikāh should eliminate community difficulties, in terms of cost, time of administration, requirements, and others. Therefore, if in practice it turns out to be difficult for some people, because of high costs or because of the distance of the location or due to legal obstacles (al-man'i) that can not be avoided, then there must be other alternative provisions so that the existence of the provision is not detrimental for Public.

Based on the perspective above, it is clear that the policy of isba nikäh as a solution for parties engaging in uncertified intermarriage is really necessary and urgent.

Apart from the provisions stated in the Law No. 1/1974, another form of restitutive legal protection for women in intermarriages can also be found in Law Number 12 of 2006 concerning Citizenship. Before the enactment of the Law, the position of women in intermarriages was very unsupported in the eyes of state law. During this situation, various cases occurred, in which mothers can not obtain justice relating to their children as the old citizenship law (Act Number 62 of 1958), not at all set about that. It was only after Law No. 12/2006 on Citizenship was ratified did the position of Indonesian women in intermarriage be better,

${ }^{25}$ A. Djazuli, Kaidah-Kaidah Fikih: Kaidah-Kaidah Hukum Islam dalam Menyelesaikan Masalah-Masalah yang Praktis, Cet. ke 3 (Jakarta: Kencana, 2010), p. 11.

${ }^{26}$ See Penjelasan atas Undang-Undang Nomor 1 Tahun 1974 tentang Perkawinan, Penjelasan Umum Nomor 3. 
as well the fate of children in the intermarriage in obtaining citizenship following their mother's status. ${ }^{27}$

Concerning the position of women in intermarriage, Law No. 12 of 2006 stated that basically intermarriage is based on the principle of following and equality. The principle of following means that the wife follows the status of her husband, both at the time when the marriage takes place and after the marriage is carried out. While the principle of equality means that marriage does not affect a person's citizenship in the sense that each husband and wife are free to choose or determine their status of citizenship. ${ }^{28}$

Furthermore, If examined in-depth, it can be said that the principle of intermarriage adhered to the Citizenship Act tends to follow the principle of equality. This can be seen in Article 26 Paragraph (1) which states that "Indonesian women married to foreign men lose their citizenship if according to the law of the husband's state the wife's citizenship follows the husband's citizenship". This article, however, is followed by another article, namely Article 26 Paragraph (3) stating if a woman wishes to retain her citizenship, then she can submit a statement of intent to the official or representative of Indonesia that can be submitted after 3 years. Indonesian women who are married to foreigners will still not lose their citizenship if they apply to the Ministry of Law and Human Rights.

Besides, the Citizenship Act, actually, also adheres to the principles that protect Indonesian women who engage in intermarriage. This principle can be found in Article 26 Paragraphs 1 and 3 concerning the principle of single citizenship (one nationality for each person). This principle is deemed relevant for Indonesian women who hold intermarriage in which they can regain their citizenship after submitting a letter of application to the Official or Representative of the Republic of Indonesia whose jurisdiction covers the area where the woman lives. ${ }^{29}$ This provision

${ }^{27}$ Margono, 'Perlindungan Hukum Terhadap Anak Hasil Perkawinan Campuran di Wilayah Kota Yogyakarta', Jurnal Jurisprudence, p. 3. <http://journals.ums.ac.id/index.php/jurisprudence/ article/view/4192>.

${ }^{28}$ Titik Triwulan Tutik, Pokok-Pokok Hukum Tata Negara (Jakarta: Prestasi Pustaka Publisher, 2006), p. 244.

${ }^{29}$ Anugerah Gilang Priandena, 'Perlindungan Hukum Bagi Anak Yang Lahir Dari 
provides restitutive protection for Indonesian women with a mechanism of returning their Indonesian citizenship status, which originally followed the husband's citizenship, by applying to the competent officials.

\section{Conclusion}

Based on the description above, it can be concluded that uncertified intermarriage is a marriage conducted by a foreign man/woman with a woman/man of Indonesian nationality. In the process of the marriages, the terms and conditions of marriage have been fulfilled but not recorded by the marriage registrar because of certain reasons, such as the incompleteness of marriage documents that results in the marriages is carried out without the acknowledgment of state institution.

Marriage law in Indonesia has protected Indonesian women who engage in unregistered intermarriages either preventively or restitutively through the Law No. 1 of 1974 about Marriage especially Article 1 Paragraph (1) and (2), Articles 57-62, Compilation of Islamic Law as well as Article 26 Paragraphs (1) and (3) of the Law No. 12 of 2006 concerning citizenship

\section{Bibliography}

Al Amin, M. Nur Kholis, 'Perkawinan Campuran dalam Kajian Perkembangan Hukum: Antara Perkawinan Beda Agama dan Perkawinan Beda Kewarganegaraan di Indonesia', Al-Ahwal: Jurnal Hukum Keluarga Islam <http://ejournal.uinsuka.ac.id/syariah/Ahwal/article/view/09206>.

Anisah, Nur, 'Pelaksanaan Perkawinan Campuran di KUA Tahunan, Jepara dalam Tinjauan Undang-Undang Perkawinan di Indonesia', Isti dal : Jurnal Studi Hukum Islam, <https://ejournal.unisnu.ac.id/ JSHI/article/view/854>.

Djazuli, A., Kaidah-Kaidah Fikih: Kaidah-Kaidah Hukum Islam dalam Menyelesaikan Masalah-Masalah Yang Praktis, Cet. ke 3. Jakarta: Kencana, 2010.

Perkawinan Campuran', Jurnal Jurisprudence, 4.1 (2017), 15-23-23 (p. 18) <https://doi. org/10.23917/jurisprudence.v4i1.4196>. 
Djawas, Mursyid, and Nurzakia Nurzakia, 'Perkawinan Campuran di Kota Sabang (Studi terhadap Faktor dan Persepi Masyarakat tentang Dampak Perkawinan Campuran)', SAMARAH: Jurnal Hukum Keluarga dan Hukum Islam, 2.2 (2019), 307-34 <https:// doi.org/10.22373/sjhk.v2i2.4740>.

Edithafitri, Ahmadika Safira, 'Status Kepemilikan Benda Tidak Bergerak dalam Perkawinan Campuran di Indonesia', LEX PRIVATUM, 3.1 (2015) <https://ejournal.unsrat.ac.id/index.php/lexprivatum/article/ view/7027>.

Faiz Nur, (A Judge ini Badung Religious Court), Motivasi orang menikahi pribumi, 2018.

Ghazaly, Justitia Henryanto, 'Kepemilikan Hak Atas Tanah dalam Perkawinan Campuran', JCH (Jurnal Cendekia Hukum), 5.1 (2019), 117-30 <https://doi.org/10.33760/jch.v5i1.183>.

Hikmah, Mutiara, 'Perlindungan Hak-Hak Perempuan dalam Perkawinan Campuran Berdasarkan Instrumen-Instrumen Internasional Tentang Hak Asasi Manusia', Indonesian Journal of International Law, 3.4 (2006), 625-641-641 <https://doi.org/10.17304/ijil.vol3.4.126>.

Julir, Nenan, 'Pencatatan Perkawinan di Indonesia Perspektif Ushul Fikih', Jurnal Ilmiah Mizani: Wacana Hukum, Ekonomi dan Keagamaan, 4.1 (2018), 53-62 <https://doi.org/10.29300/mzn.v4i1.1010>.

Karyadi dan Mursal, (Registrars in Religious Court of Denpasar and Tabanan), 2018.

Khosiah, Siah, dkk., Isbāt Nikāh Atas Perkawinan Campuran Pada Wilayah Wisata Di Indonesia. Bandung: Lembaga Penelitian dan Pengabdian kepada Masyarakat, 2018.

Mahmudah, (A Judge of Religious Court of Badung), 2018.

Margono, 'Perlindungan Hukum Terhadap Anak Hasil Perkawinan Campuran di Wilayah Kota Yogyakarta', Jurnal Jurisprudence, <http:// journals.ums.ac.id/index.php/jurisprudence/article/view/4192>.

Masruhan (Head of Religious Court of Southern Kuta Region), 2018. Partogi, Sebastian, 'Implications of Mixed Marriage for Indonesian Women' Property Ownership - Business - The Jakarta Post' <https://www. 
thejakartapost.com/news/2015/09/12/implications-mixed-marriageindonesian-women-s-property-ownership.html>.

Priandena, Anugerah Gilang, 'Perlindungan Hukum Bagi Anak yang Lahir dari Perkawinan Campuran', Jurnal Jurisprudence, 4.1 (2017), 15-23-23 <https://doi.org/10.23917/jurisprudence.v4i1.4196>.

Putri, Raesa Astiti, Yunanto, 'Pengangkatan Anak Warga Negara Indonesia Oleh Orang Tua Angkat dalam Perkawinan Campuran di Indonesa (Studi Kasus: Pengangkatan dalam Kasus Angeline di Bali)', Diponegoro Law Journal, 5.2 (2016), 1-13.

Purwaningsih, Sri Budi, 'Perlindungan Hukum Kedudukan Anak Luar Kawin Pasca Putusan Mahkamah Konstitusi No: 46/PUU-VIII/2010', Jurnal Rechtsidee, 1.1 (2014), 5.

R. Damayanti, Kajian Akademis Rencana Program 30 Tahun Menghadirkan Manusia Indonesia Baru (Peluang Pengkondisian Perkawinan Antar Etnis, Ras, Bangsa dan Agama di Indonesia). Jakarta: Kementerian Pemberdayaan Perempuan dan Perlindungan Anak. Pusat Penelitian Kesehatan Universitas Indonesia, 2015.

Rampay, Darwis L. 'Hak Waris Anak dalam Perkawinan Campuran Berdasarkan Undang-Undang Nomor 12 Tahun 2006 Tentang Kewarganegaraan', MORALITY : Jurnal Ilmu Hukum'. <http://jurnal. upgriplk.ac.id/index.php/morality/article/view/27>.

Sumner, Cate dkk, Studi Dasar AIPJ Tentang Identitas Hukum Jutaan Orang Tanpa Identitas Hukum di Indonesia. Jakarta: DFAT, 2014.

Sururie, Ramdani Wahyu, 'Polemik di Seputar Hukum Isbāt Nikāh dalam Sistem Hukum Perkawinan Indonesia', Al-Manahij: Jurnal Kajian Hukum Islam. <http://ejournal.iainpurwokerto.ac.id/index. php/almanahij/article/view/1299>.

S, Laurensius Arliman, 'Peran Lembaga Catatan Sipil Terhadap Perkawinan Campuran Berdasarkan Undang-Undang Perkawinan', JCH (Jurnal Cendekia Hukum), 4.2 (2019), 288-301 <https://doi.org/10.33760/ jch.v4i2.40>.

Tektona, Rahmadi Indra, 'Perlindungan Hukum Perempuan Terhadap Anak Hasil Perkawinan Campuran di Indonesia (Perspektif Socio- 
Legal)', MUWAZAH: Jurnal Kajian Gender, <http://e-journal. iainpekalongan.ac.id/index.php/Muwazah/article/view/267>.

Tutik, Titik Triwulan, Pokok-Pokok Hukum Tata Negara. Jakarta: Prestasi Pustaka Publisher, 2006.

Umar, 'Nasaruddin, Hukum Keluarga Kontemporer di Negara-Negara Muslim' (presented at the Seminar Nasional Hukum Materil Peradilan Agama, Antara Cita, Realita dan Harapan, Hotel Red Top, Jakarta, 2010). 